\title{
Experimental Investigation of Biogas Production from Kitchen Waste Mixed with Chicken Manure
}

\author{
H. Mousaa,b,* A. Obaidat ${ }^{b}$, H.B. Khaled ${ }^{b}$, A. Alawaneh ${ }^{b}$ and A. Tarawneh ${ }^{b}$ \\ a Department of Petroleum and Chemical Engineering, College of Engineering, Sultan Qaboos University, Oman. \\ ${ }^{b}$ Department of Chemical Engineering, Jordan University of Science and Technology, Jordon.
}

Received 23 October 2015; Accepted 8 December 2015

\begin{abstract}
Biogas produced from solid kitchen waste (KW) mixed with chicken manure (M) at different mass ratios was investigated. The effect of the ratio of the amount of water to the mixed solid waste on the amount of biogas produced was studied. The results showed that at a fixed ratio of water-to-solid waste, the amount of biogas increased as the amount of chicken $\mathrm{M}$ increased. At a fixed M-to-KW ratio, the amount of biogas produced increased as the solid content increased and then decreased, reaching its maximum value at a solid waste-to-water ratio of 1:1. The $\mathrm{pH}$ of the bioreactor containing the KW-M mixture dropped with time, resulting in a decrease in the amount of biogas produced. Controlling the $\mathrm{pH}$ value by titrating with $\mathrm{NaOH}$ solution improved the production of biogas. Investigating biogas produced from sludge showed that the $\mathrm{pH}$ of the reactor slightly decreased and then increased slightly. The results also showed that the amount of biogas produced from sludge containing 3\% solid waste was larger than the amount produced from sludge containing $6 \%$ solid waste.
\end{abstract}

Keywords: Biogas, Waste to energy, Methane, Renewable energy, Bioreactor, Fermentation, Biodegradation.

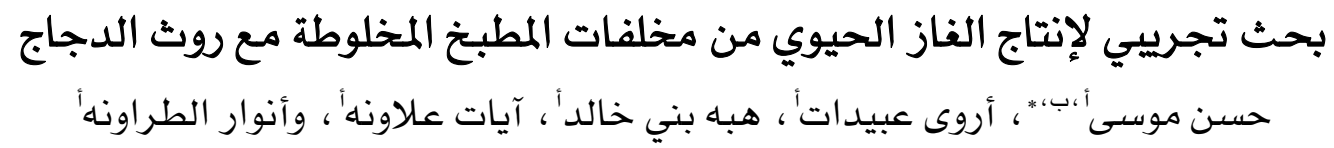

الملخص: تم دراسـة الغاز الحيوي المنتج من مخلفات المطبخ الصلبة المخلوطة بنسب كتلية مختلفة من روث الدجاج. وتم تتبع نسب المياه المضافة الى هذا الخليط لمعرفة تأثيرها على كمية الغاز الحيوي المنتج. وأظهرت النتائج أنه مع تثبيت نسب المياه المضافة الى المخلفات الصلبة أن كمية الغاز الحيوي المنتج تزداد مع زيادة كمية روث الدجاج. أما عند تثبيت نسب روث الدجاج الى مخلفات المطبخ الصلبة فان كمية الغاز الحيوي المنتج تزداد مع زيادة مخلفات المطبخ الصلبة ثم تبدأ بالتتاقص، بحيث تصل الى أقصى قيمه لها عندما تكون نسبة المخلفات الصلبة الى الماء ا:1. كهما هبطت درجة الحموضة مع مرور الوقت وِ المفاعل الحيوي الذي يحتوي على خليط مخلفات المطبخ الصلبة وروث الدجاج، مؤديًا الى انخفاض ِوْ كمية الغاز الحيوي المنتج. ولكن عندما تم التحكم بقيمة الرقم الهيدروجيني للحموضة من خلال المعايرة بهحلول هيدروكسيد الصوديوم فان ذلك قام بتحسـين إنتاجية الغاز الحيوي. كها إن تتبع الغاز الحيوي المنتج من مخلفات محطة التتقية أظهر أن الرقم الهيدروجيني للحموضة يخٌ المفاعل الحيوي قد انخفض قليلًا ثم ارتفع قليلًا. كما أظهرت النتائج أن كمية الغاز الحيوي المنتج من مخلفات محطة التقية التي تحتوي على مخلفات صلبة بنسبة ب٪ تكون أعلى من تلك التي تحتوي على مخلفات صلبة بنسبة 7 \% الكلمات المفتاحية: غاز حيوي، مخلفات الى طاقة، ميثان، طاقة متجددة ، مفاعل حيوي، تخمير، تحلل عضوي.

*Corresponding author's email: hasana@squ.edu.om. 


\section{Introduction}

One of the most important factors in human wellbeing is energy. Providing sufficient amounts of reasonably priced energy is necessary to reduce poverty, improve life conditions, and promote living standards. Currently, the main source of energy for the world's industries and individuals is fossil fuel; however, as it is a nonrenewable resource, it is becoming more and more precious. Another concern related to the use of fossil fuels is the environmental pollution it causes, resulting in global warming, and water, air, and soil contamination. As such, enormous efforts are being directed towards using renewable energy sources, mainly solar, wind, and bioenergy, in place of fossil fuels.

Biogas production from solid waste mainly in the form of kitchen waste (KW), has received special attention by governments, societies, and researchers. The literature contains vast amounts of research focusing on biogas produced from a combination of $\mathrm{KW}$, sludge, and agricultural waste and determining the optimum conditions for biogas production.

Liu et al. (2008) investigated methane production from a mixture of stover and food waste mixed with activated sludge (inoculums) in a batch reactor under mesophilic $\left(35^{\circ} \mathrm{C}\right)$ and thermophilic $\left(55^{\circ} \mathrm{C}\right)$ conditions. The effect of the $\mathrm{pH}$ and solid content on the biogas productivity was investigated. The results showed that biogas productivity under mesophilic conditions yielded a $\mathrm{pH}$ of 7 with a higher solid content. Similarly, biogas produced from grass (cocksfoot, tall fescue, reed canary, and timothy) was studied by Seppl et al. (2009). They found that the methane yield per hectare of the first harvest was always higher than that of the second harvest; however, all the grass types were suitable producers of biogas.

Bouallagui et al. (2003) studied the production of biogas from fruit and vegetable waste under mesophilic conditions in a semicontinuous tubular digester. The effect of the hydraulic retention time (HRT) and feed concentration on the extent of the degradation of the waste was investigated. The results showed that the biogas produced contained $64 \%$ methane. Similar results were found by Lianhua et al. (2010) and Sánchez et al. (2000). Production of biogas from wastewater sludge was studied by Ferrera et al. (2008) under thermophilic conditions in a semi-continuous reactor. Their results showed that biogas production increased by $30 \%$ upon pretreatment of the sludge under thermophilic conditions. Noutsopoulos et al. (2012) investigated the increase in biogas production by co-digesting lipids in sewage sludge. They found that biogas production increased when the lipid was mixed with the sludge, and the production was proportional to the lipid concentration. The effect of adding fatty acids to sludge on biogas production under thermophilic conditions was studied by Lins and Illmer (2012). It was found that after certain concentrations, fatty acids initially prevented biogas production; however, production then continued. Sludge pretreatment at $70^{\circ} \mathrm{C}$ in a microwave showed that biogas production could be improved up to $35 \%$ (Kuglarz et al. 2013).

Castrillón et al. (2013) studied methane production from cattle manure (M) supplemented with crude glycerin from the biodiesel industry in a continuously stirred tank reactor (CSTR) and induced bed reactor. The results showed that biogas production greatly depends on the organic loading rate (OLR). Biogas production from whey mixed with poultry $\mathrm{M}$ was investigated by Gelegenisa $e t a l$. (2007a) in a CSTR with an OLR of 4.9g COD/Ld. It was found that biogas production increased by $40 \%$. Similar results were found by Castrillón et al. (2011) when glycerin was mixed with cattle M. Biogas production from cow and llama M was studied by Alvareza et al. (2006), showing that the llama $\mathrm{M}$ gave better results than cow $\mathrm{M}$ since it contains a higher volatile solid (VS) content. Biogas production from food waste mixed with animal $\mathrm{M}$ was also investigated by Marañón et al. (2012); Budiyono et al. (2014); and Azadeh and Jalal (2011).

The objective of the current research was to investigate the production of biogas from solid $\mathrm{KW}$ mixed with chicken $\mathrm{M}$ at different KW-M mass ratios. The effect of the solid content and $\mathrm{pH}$ on the amount of biogas produced was also studied. Biogas production from sludge and sludge mixed with $\mathrm{KW}$ was also investigated.

\section{Methodology}

\subsection{Setup}

One-liter squeeze bottles were used as bioreactors. The required amount of water, solid waste prepared a priori, and M were well mixed and placed in the bottles. The bottles' 
temperatures were held constant at $35 \pm 1^{\circ} \mathrm{C}$ by immersing the bottles in a water bath where the temperature was held constant by an external heater and controller. The bottle mouth was connected to a syringe to measure the volume (V) of the biogas produced over time. Under the assumption that the gas was ideal, the moles of the biogas produced (n) were calculated using the ideal gas law

$n=\frac{P V}{R T}$

where $\mathrm{T}$ is the temperature, $\mathrm{P}$ is the atmospheric pressure, and $\mathrm{R}$ is the universal gas constant.

\subsection{Materials}

A mixture of vegetables and fruits (200 $\mathrm{g}$ of cucumber, tomatoes, orange peel, rice, cabbage, apple, and carrot in equal amounts) represented the KW and was used in this study. The vegetables and fruits were cut into small species $(0.5 \mathrm{~cm} \times 0.5 \mathrm{~cm} \times 0.5 \mathrm{~cm})$ and mixed with the required amount of chicken was then added as required, and the mixture was well agitated and introduced to the bottles, which were submersed in the water bath.

\subsection{Procedure}

The effect of the solid content was tested by adding the required amount of water to the $\mathrm{KW}-\mathrm{M}$ mixture, which was termed as solid (S). The following S-water ratios were tested: 1:0 (100\% S; no water added), 3:1, 1:1, and 1:3, hence obtaining a $S$ content of $100 \%, 75 \%, 50 \%$, and $25 \%$, respectively.

The effect of the amount of $M$ to the $K W$ was tested by adding certain amounts of $\mathrm{M}$ to the KW so that the ratio of KW:M was 1:0, 3:1, 1:1, and 1:3, hence obtaining percentages of $K W$ in the KW-M mixture of $100 \%$ (pure $\mathrm{KW}$ ), $75 \%$, $50 \%$ and $25 \%$, respectively.

The produced gas samples were analyzed for methane content using an Eagle gas analyzer (RKI Instruments, Union City, California, USA). The $\mathrm{pH}$ of the mixture was measured via a $\mathrm{pH}$ meter WTW Wissenschaftlich-Technische Werkstätten $\mathrm{GmbH}$, Weilheim in Oberbayern, Germany). The VS contents were measured according to the standard procedures.

\section{Results and Discussion}

\subsection{Effect of Solid: Water Ratio}

The effect of the $S$ : Water ratio on the amount of biogas produced is depicted in Fig. 1. When the ratio of KW: $\mathrm{M}$ in the solid mixture was 1:1, the VS content in the solid mixture was $78 \%$. Figure 1 shows that the production rate was fast on the first day and then slowed down, possibly because the acidogensis bacteria degraded the manure faster compared to the vegetables. The fatty acid concentrations increased in the mixture as a result of this step. Accordingly, the $\mathrm{pH}$ dropped, reducing the activity of the methanogenic bacteria and, consequently the production of biogas (Beam 2011; Dearman et al. 2006; Raposo et al. 2006; Xu et al. 2002; Yadvika et al. 2004). Figure 1 also shows that an optimum S:Water ratio of 1:1 existed at the point where the highest production of biogas was obtained, which is a result similar to that obtained by Gelegenis et al. (2007b).

\subsection{Effect of KW: M Ratio}

The effect of the ratio of KW: $\mathrm{M}$ on biogas production when the S: Water ratio equaled 1:1 is depicted in Fig. 2. As expected, the amount of biogas produced increased as the amount of $\mathrm{M}$ increased, or as the ratio of $\mathrm{KW}$ : $\mathrm{M}$ decreased, since $M$ degrades faster than KW. It should be noted that the VS content of the solid mixture $(\mathrm{KW}+\mathrm{M})$ was $78 \%$.

\subsection{Biogas Production from Sludge}

Biogas produced from sludge containing $94 \%$ water and $97 \%$ water is portrayed in Fig. 3. The sludge was obtained from a nearby waste water treatment plant and contained $94 \%$ water. The sludge was then diluted further with water to obtain a saturation level of $97 \%$. The rate of biogas production was faster for the diluted sludge, and a larger amount of biogas was obtained. This result is in accordance with the results obtained by AbdAlaal (2012).

\subsection{Effect of pH on the Biogas Production}

As the fermentation process proceeds, fatty acids are produced from organic waste by the acidogenesis of bacteria; accordingly, the $\mathrm{pH}$ value of the mixture drops. This causes a drop in the activity of the bacteria, especially the ethanogenic bacteria (Dearman et al. 2006; Raposao et al. 2006; Ryan 2011; Yadvika et al. 2004).

A measurement of the $\mathrm{pH}$ of the mixture as a function of time during the digestion of the KW$\mathrm{M}$ concoction is shown in Fig. 4. The rate of biogas production was high at the beginning of the process, but after day four it stopped. The $\mathrm{pH}$ value, however, dropped from 6.5 to 3.5 and 


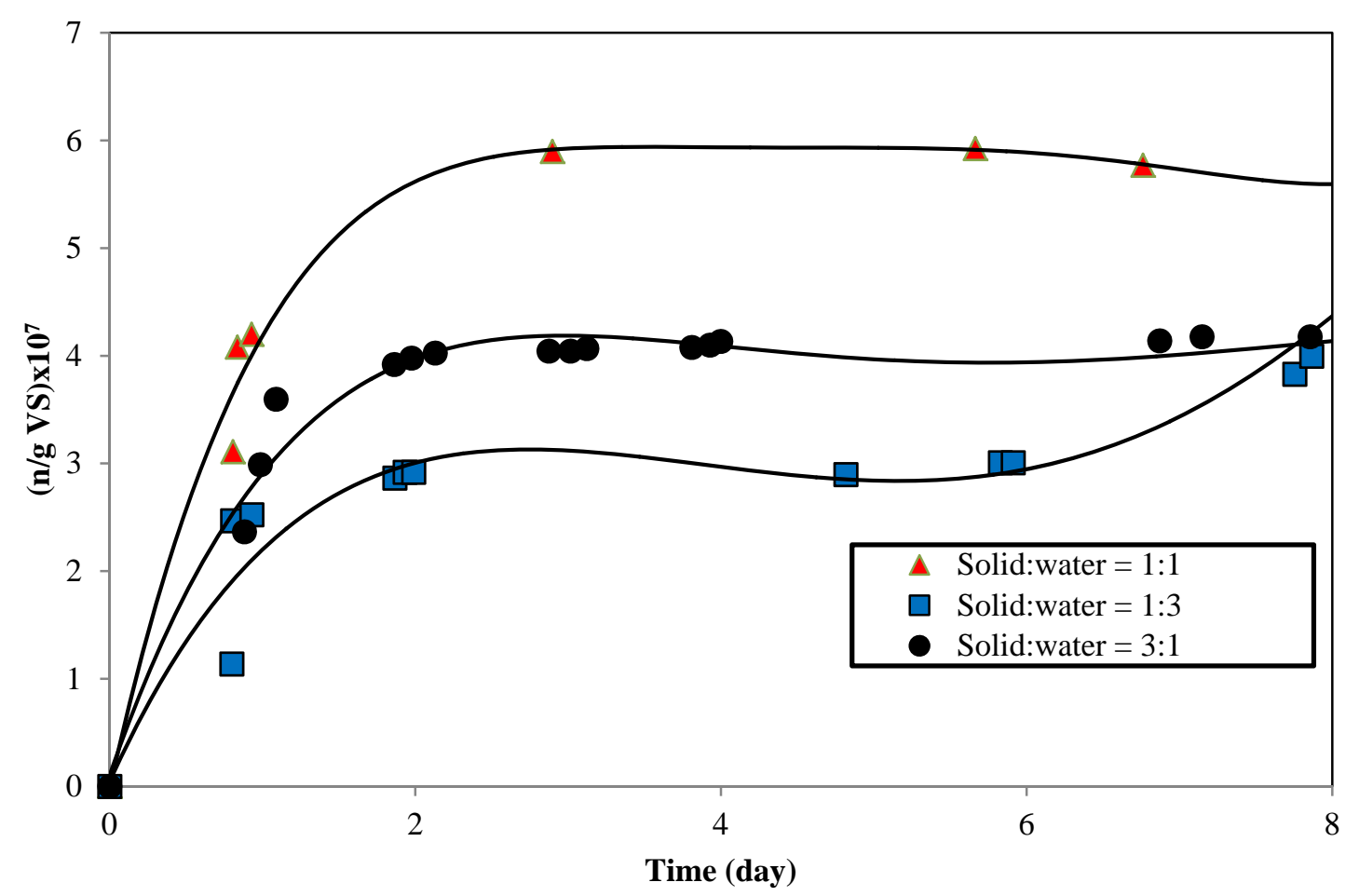

Figure 1. Amount of biogas produced versus time at $35^{\circ} \mathrm{C}$ for various solids, water ratios with $\mathrm{KW}$ : M ratio of 1:1.

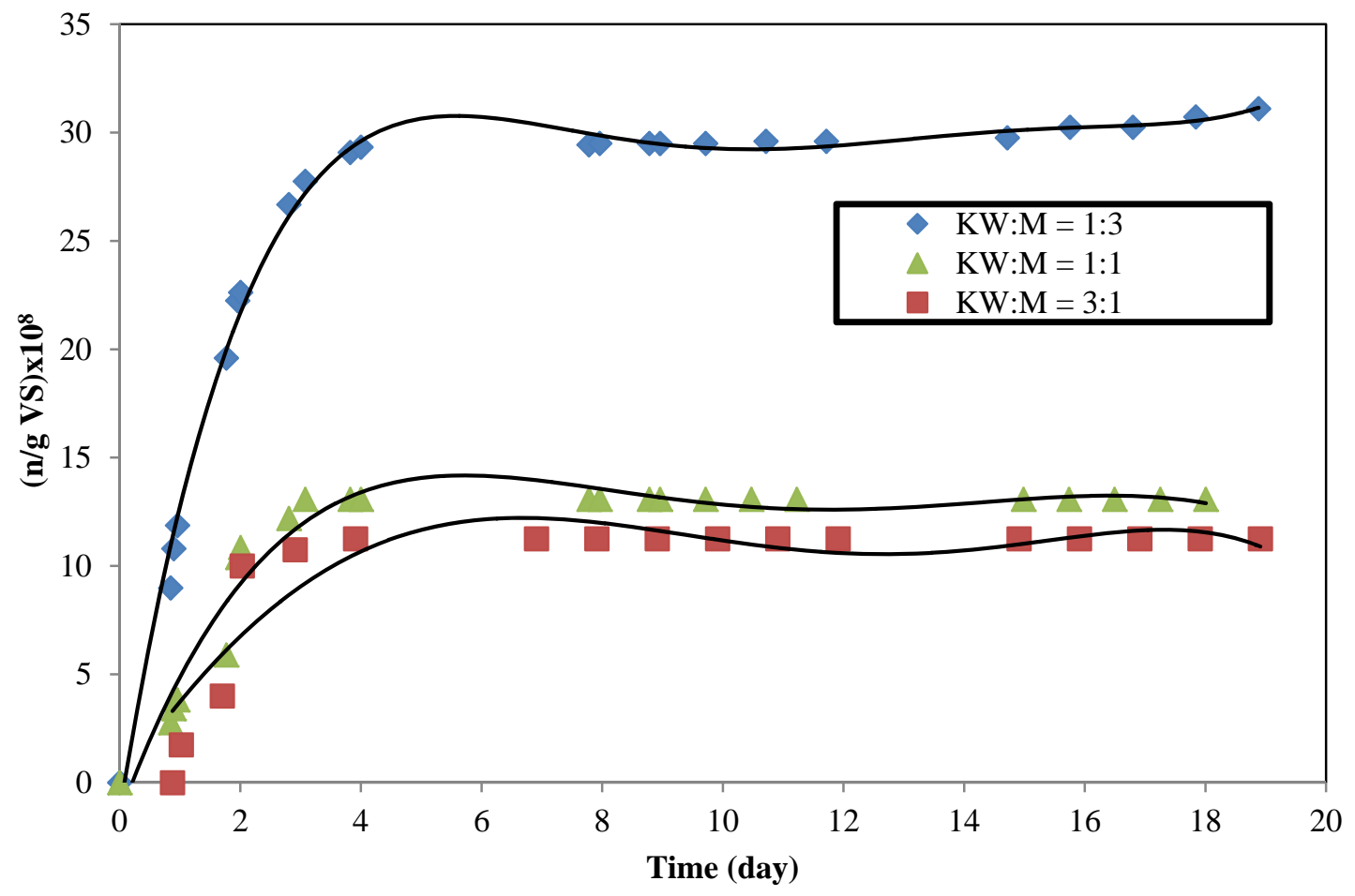

Figure 2. Effect of KW : M ratio on the amount of biogas produced with solid : water ratio of 1:1. 


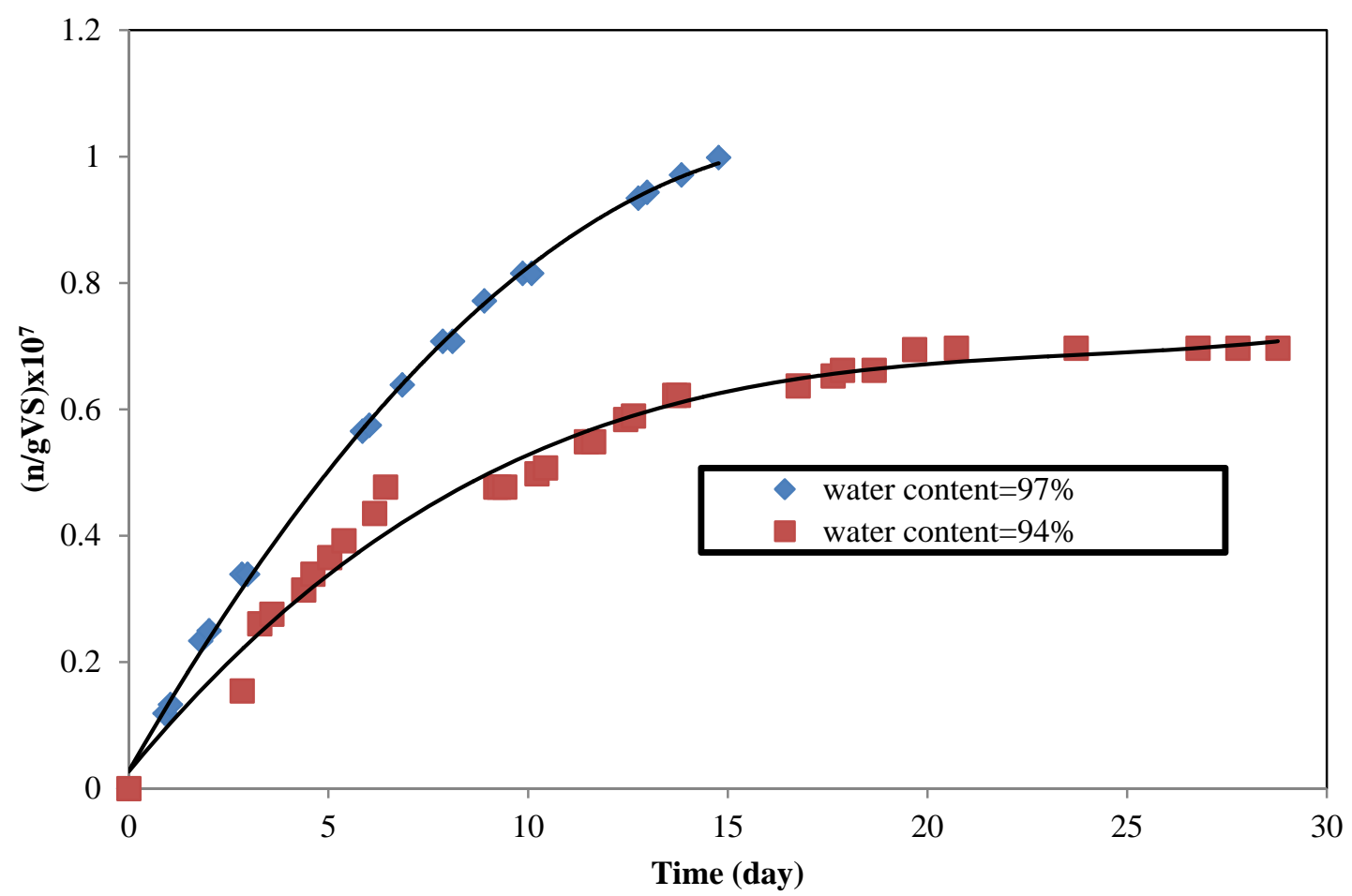

Figure 3. The amount of biogas produced versus time from waste water sludge at $35^{\circ} \mathrm{C}$.

then stopped, indicating that there was no bacterial activity after four days, which also reflected on the biogas production as no biogas was produced after four days.

To study this point further, the same experiment was repeated under the same conditions except that the $\mathrm{pH}$ was kept constant at 6 by adding a $\mathrm{NaOH}$ solution. The results are illustrated in Fig. 5, where it can be seen that the process of biogas production continued for 12 days and then stopped.

A similar experiment on sludge with a water content of $94 \%$ was performed. No effort was made to control the $\mathrm{pH}$. The results are shown in Fig. 6, where it can be seen that the rate of biogas production continued until day 12 after which it slowed down. It can be also seen that the $\mathrm{pH}$ dropped slightly after the first day and then slowly increased. This result was different from that obtained for KW-M (Fig. 4) where the $\mathrm{pH}$ continuously decreased. This might be attributed to the high amount of water in the sludge sample. This result was in accordance with the results of AbdAlaal (2012) and Kalloum et al. (2011). However, the current researchers believe that this point needs further investigation.

\subsection{Effect of Temperature}

The effect of temperature is shown in Fig. 7 where, as expected, biogas gas production rates increased as the temperature increased. This result is in accordance with other researches' results (Beam 2011; Chua et al. 2013).

\section{Conclusion}

Biogas produced from the anaerobic digestion of KW mixed with chicken $\mathrm{M}$ was investigated. The effect of the ratio of KW mass to that of $\mathrm{M}$ in a mixture containing a constant amount of water on the production rate of biogas was studied. The results showed that the lower the ratio of KW:M the higher the quantity of biogas that was produced. Investigating the effect of water on biogas production showed that the amount of biogas produced versus the $\mathrm{S}: \mathrm{W}$ ratio went through a maxima which existed at a $\mathrm{S}: \mathrm{W}$ ratio of 1:1. Controlling the $\mathrm{pH}$ at $\sim 6$ resulted in the highest yield of biogas. Acidic or basic conditions negatively affected the biogas production. Sludge with a lower solid content yielded a better biogas production rate. Biogas production at $35^{\circ} \mathrm{C}$ was greater than at $25^{\circ} \mathrm{C}$. 


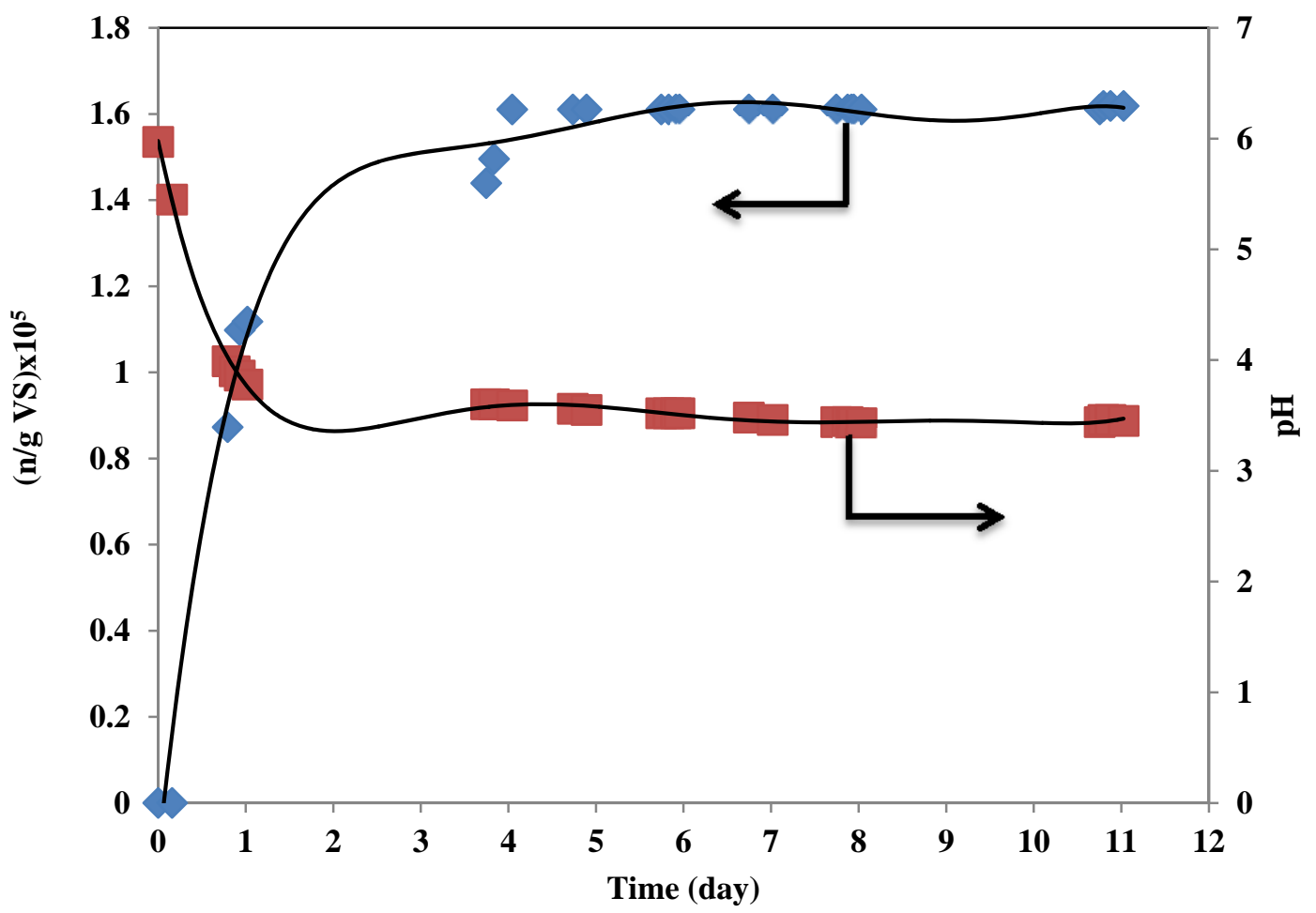

Figure 4. Measured the $\mathrm{pH}$ and the amount of biogas produced for $\mathrm{KW}: \mathrm{M}$ ratio of 1:1 and solid : water ratio of $1: 1$ at $35^{\circ} \mathrm{C}$.

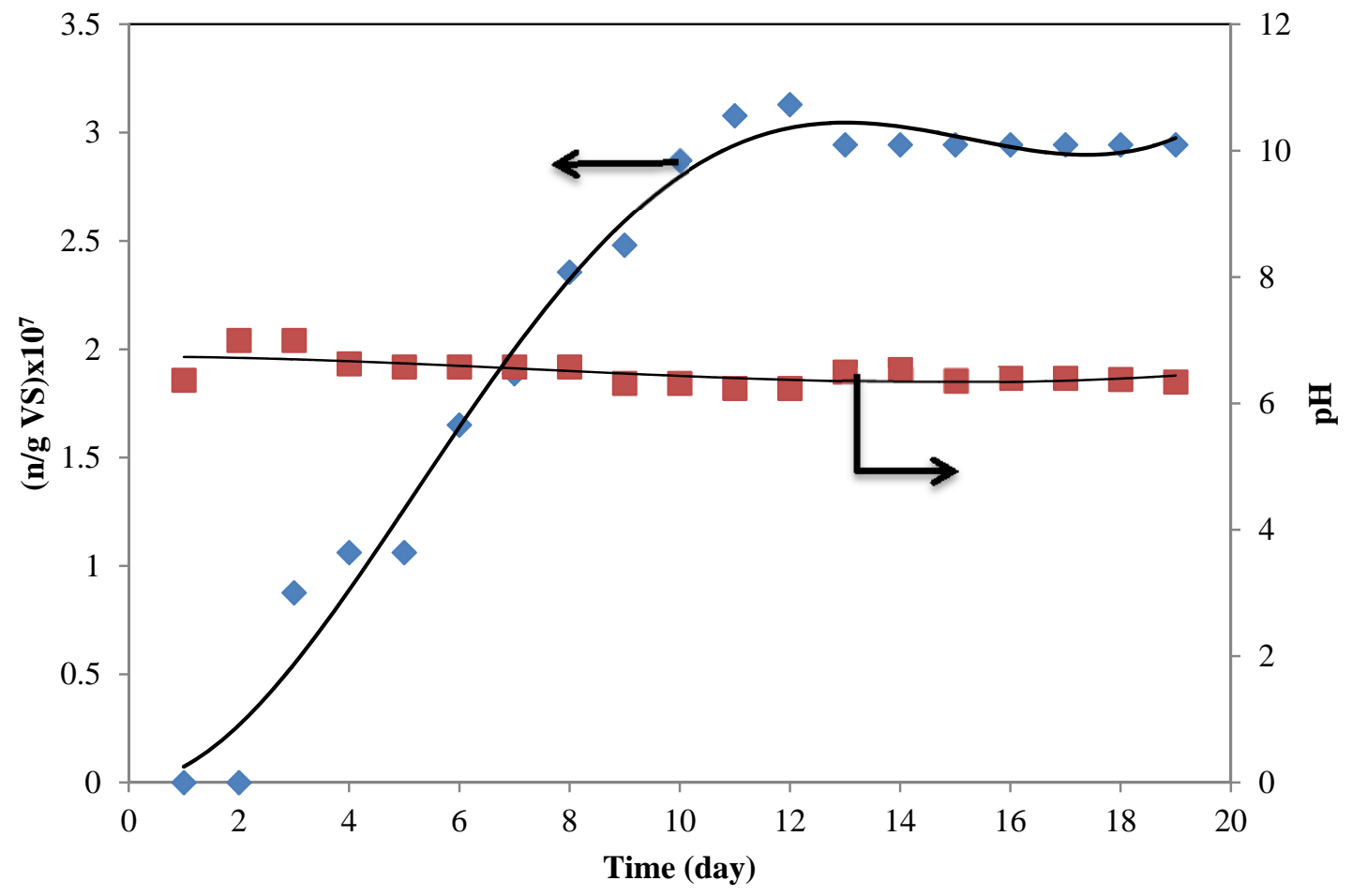

Figure 5. Measured amount of biogas produced at constant $\mathrm{pH}$ value for a $\mathrm{KW}: \mathrm{M}$ ratio of 1:1 at $35^{\circ} \mathrm{C}$. 


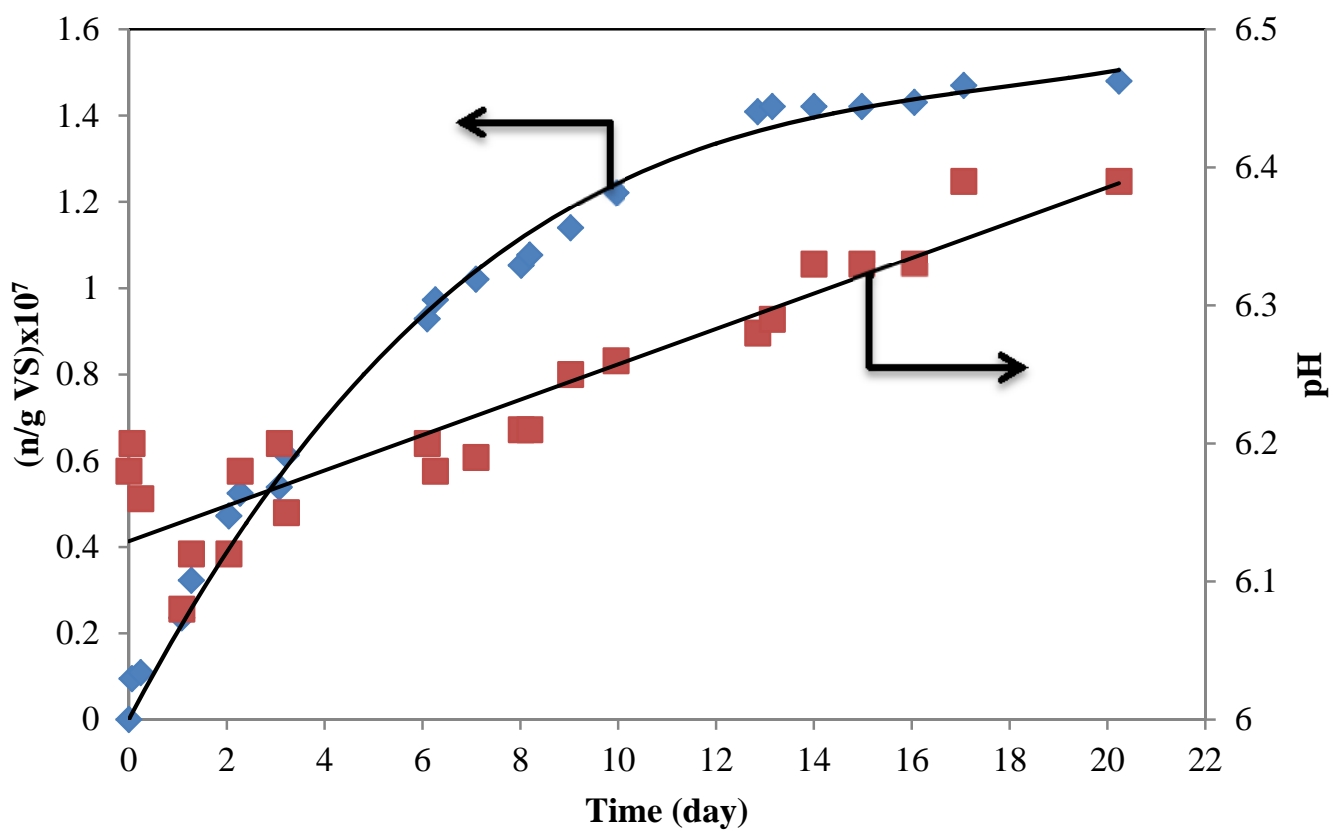

Figure 6. Amount of biogas produce from sludge sample of water content of $94 \%$ at $\mathrm{T}=35^{\circ} \mathrm{C}$.

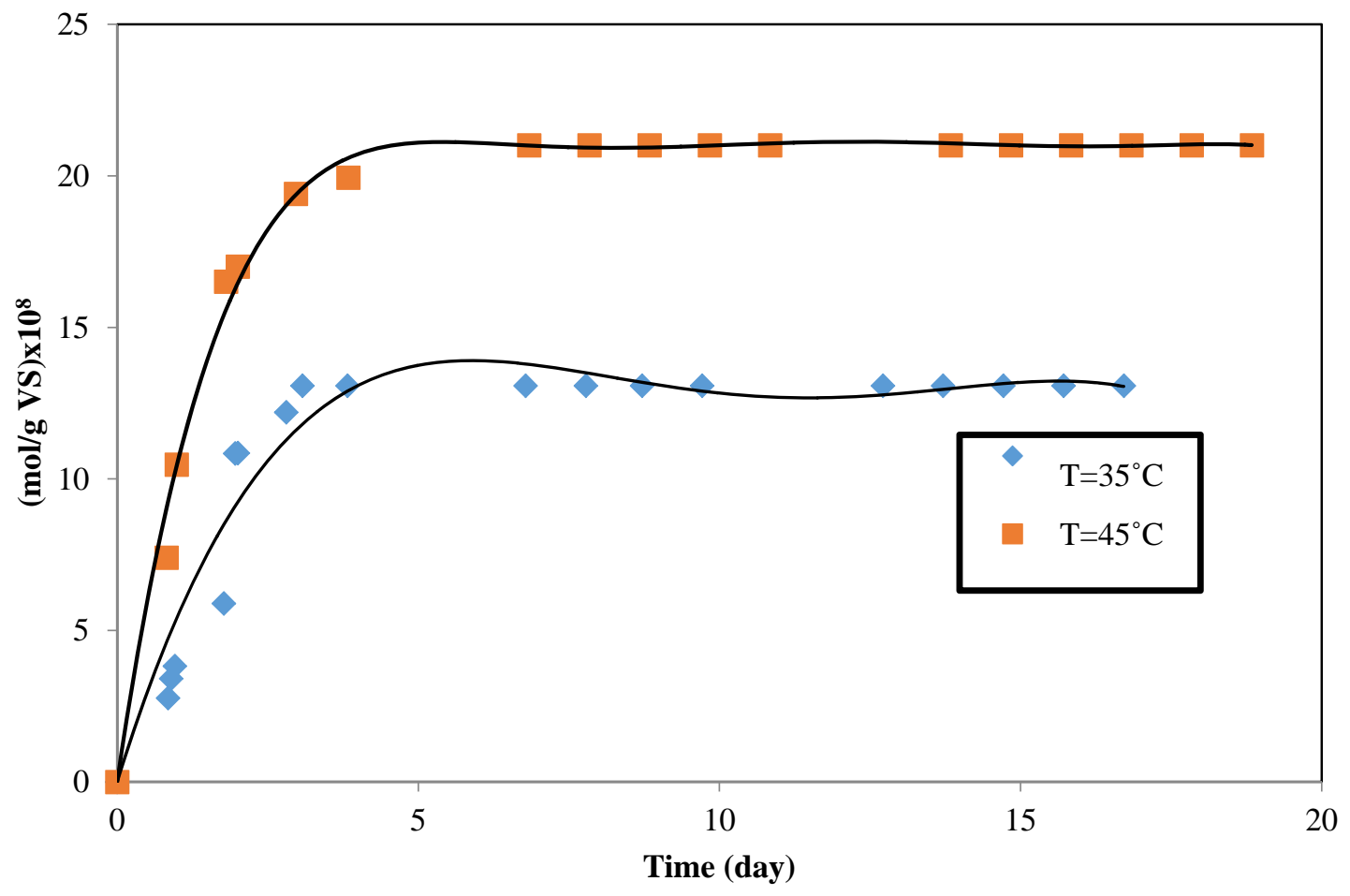

Figure 7. Effect of temperature on the amount of gas produced solid : water =1:1 and KW : M=1:1. 


\section{References}

AbdAlaal R (2012), Potential production of biogas from the sludge of the wastewater treatment plant at Jordan University of Science and Technology, M.Sc. Thesis.

Alvareza R, Villcaa S, Lidénb G (2006), Biogas production from llama and cow manure at high altitude. Biomass and Bioenergy 30: 66-75.

Azadeh B, Jalal S (2011), Effect of organic loading rates (OLR) on production of methane from anaerobic digestion of vegetables waste. World Renewable Energy Congress, Linkoping, Sweden, May 8-13.

Beam R (2011), Enhanced biogas production through the optimization of the anaerobic digestion of sewage sludge, M.Sc. thesis. The University of Alabama.

Bouallagui H, Ben R, Cheikh B, Marouani L, Hamdi M (2003), Mesophilic biogas production from fruit and vegetable waste in a tubular digester. Bioresource Technology 86: 85-89.

Budiyono N, Widiasa N, Seno J, Sunarso L (2014), Increasing biogas production rate from cattle manure using rumen fluid as inoCulums. International Journal of Science and Engineering 6: 31-38.

Castrillón L, Fernández-Nava Y, Ormaechea P, Marañón E (2013), Methane production from cattle manure supplemented with crude glycerin from the biodiesel industry in CSTR and IBR. Bioresource Technology 127: 312-317.

Castrillón L, Fernández-Nava Y, Ormaechea, P, Marañón E (2011), Optimization of biogas production from cattle manure by pretreatment with ultrasound and co-digestion with crude glycerin. Bioresource Technology 102: 7845-7849.

Chua K, Cheah W, Tan C, Leong Y (2013), Harvesting biogas from wastewater sludge and food waste. $4^{\text {th }}$ International Conference on Energy and Environment (ICEE 2013). Earth and Environmental Science 16: 012118.

Dearman P, Marschner R, Bentham H (2006), Methane production and microbial community structure in single-stage batch and sequential batch systems anaerobically codigesting food waste and biosolids. Applied Microbiol Biotechnology 69: 589-596.

Ferrera I, Ponsáb S, Vázquezc F, Xavier F (2008), Increasing biogas production by thermal $\left(70^{\circ} \mathrm{C}\right)$ sludge pre-treatment prior to thermophilic anaerobic digestion. BioChemical Engineering Journal 42: 186-192.
Gelegenis J, Georgakakis D, Angelidaki I, Christopoulou N, Goumenaki M (2007a), Optimization of biogas production from oliveoil mill wastewater, by codigesting with diluted poultry-manure. Applied Energy 84: 646-663.

Gelegenisa J, Georgakakisb D, Angelidakic I, Mavrisa V (2007b), Optimization of biogas production by co-digesting whey with diluted poultry manure. Renewable Energy 32: 21472160.

Kalloum S, Bouabdessalem H, Touzi A, Iddou A, Ouali M (2011), Biogas production from the sludge of the municipal wastewater treatment plant of Adrar city (southwest of Algeria). Biomass and Bioenergy 35: 2554-25560.

Kuglarz M, Karakashev D, Angelidaki I (2013), Microwave and thermal pretreatment as methods for increasing the biogas potential of secondary sludge from municipal wastewater treatment plants. Bioresource Technology 134: 290-297.

Lianhua L, Dong L, Yongming S, Longlong M, Zhenhong Y, Xiaoying K (2010), Effect of temperature and solid concentration on anaerobic digestion of rice straw in South China. International Journal of Hydrogen Energy 35: 7261-7266.

Lins P, Illmer P (2012). Effects of volatile fatty acids, ammonium and agitation on thermophilic methane production from biogas plant sludge in lab-scale experiments. Folia Microbiologica, 57: 313-316.

Liu C, Yuan X, Zeng G, Li W, Li J (2008) Prediction of methane yield at optimum $\mathrm{pH}$ for anaerobic digestion of organic fraction of municipal solid waste. Bioresource Technology 99: 882-888.

Marañón E, Castrillón L, Quiroga G, FernándezNava Y, Gómez L, García M (2012), Codigestion of cattle manure with food waste and sludge to increase biogas management. Waste Management 32: 1821-1825.

Noutsopoulos C, Mamais D, Antoniou K, Avramides C (2012), Increase of biogas production through co-digestion of lipids and sewage sludge. Global Nest Journal 14: 133-140.

Raposo F, Banks C, Siegert I, Heaven S, Borja R (2006), Influence of inoculum to substrate ratio on the biochemical methane potential of maize in batch tests. Process Biochemistry 41: 1444-1450.

Ryan G (2011), Enhanced biogas production through the optimization of the anaerobic digestion of sewage sludge. PhD thesis, The 
University of Alabama, Department of Chemical and Biological Engineering.

Sánchez E, Borja R, Weiland P, Travieso L, Martõán A (2000), Effect of temperature and $\mathrm{pH}$ on the kinetics of methane production, organic nitrogen and phosphorus removal in the batch anaerobic digestion process of cattle manure. Bioprocess and Biosystems Engineering 22: 247-252.

Seppl M, Paavola T, Lehtomki A, Rintala J
(2009), Biogas production from boreal herbaceous grasses - Specific methane yield and methane yield per hectare. Bioresource Technology 100(12): 2952-2958.

Xu H, Wang J, Tay J (2002), A hybrid anaerobic solid-liquid bioreactor for food waste digestion. Biotechnology Letters, 24: 757-761.

Yadvika S, Sreekrishnan T Sangeeta KVR (2004), Enhancement of biogas production from solid substrates using different techniques - a review. Bioresource Technology 95: 1-10. 